\title{
The role of STAT proteins in growth hormone signaling
}

\author{
James Herrington ${ }^{1}$, Lisa S Smit ${ }^{1}$, Jessica Schwartz ${ }^{1}$ and Christin Carter-Su ${ }^{*, 1}$ \\ ${ }^{1}$ Department of Physiology, University of Michigan Medical School, Ann Arbor, Michigan, MI 48109-0622, USA
}

\begin{abstract}
Growth hormone (GH) has long been known to be the body's primary regulator of body growth and a regulator of metabolism, yet the mechanisms by which GH regulates the transcription of specific genes required for these processes are just now being delineated. GH binding to its receptor recruits and activates the receptor-associated JAK2 that in turn phosphorylates tyrosines within itself and the GH receptor. These tyrosines form binding sites for a number of signaling proteins, including members of the family of signal transducers and activators of transcription (STAT). Among the known signaling molecules for GH, STAT proteins play a particularly prominent role in the regulation of gene transcription. This paper will review what is currently understood about which STAT proteins are regulated by $\mathrm{GH}$, how they are regulated by GH, the GH-dependent genes they regulate, and discuss current theories about how GH-activated STAT signaling is regulated. Particular attention will be given to the novel role that STAT5 plays in sexually dimorphic gene expression in the liver as determined by the secretory pattern of GH and the role of STAT5 in body growth. Oncogene (2000) 19, 2585-2597.
\end{abstract}

Keywords: growth hormone (GH); STAT proteins; tyrosines

\section{Introduction}

Despite the importance of growth hormone $(\mathrm{GH})$ in the regulation of body growth and metabolism, the mechanisms by which $\mathrm{GH}$ regulates the transcription of specific genes required for these processes are just now being delineated. The GH receptor was the first member of the cytokine receptor family to be cloned (Leung et al., 1987) and to be recognized as associating with and activating a tyrosine kinase (Carter-Su et al., 1989; Endo et al., 1997; Foster et al., 1988; Wang et al., 1993). GH binding to its receptor is now known to recruit and activate the receptor-associated JAK2 that in turn phosphorylates tyrosines within itself and the $\mathrm{GH}$ receptor. These tyrosines form binding sites for a number of signaling proteins, including members of the family of signal transducers and activators of transcription (STAT). Other signaling proteins that are recruited to JAK2/GH receptor complexes and/or activated in response to GH include: (1) Shc proteins that are thought to lead to the activation of the RasMAP kinase pathway; (2) insulin receptor substrates that have been implicated in the activation of phosphatidylinositol-3'-kinase and the kinase AKT/ PKB; (3) phospholipases that lead to formation of diacylglycerol and activation of protein kinase $C$; and

*Correspondence: C Carter-Su
(4) a variety of proteins that are involved in the regulation of the cytoskeleton, including focal adhesion kinase (reviewed Smit et al., 1999), paxillin, tensin, CrkII, c-Src, c-Fyn, c-Cbl and Nck (Zhu et al., 1998a,b). Among these signaling molecules, STAT proteins play a particularly prominent role in the $\mathrm{GH}$ regulation of gene transcription. This paper will review the mechanism of GH activation of STATs, regulation of STAT activation/deactivation, and the physiological consequences of disrupted GH signaling via STATs.

\section{Mechanism of activation of STAT proteins by GH}

An important pathway by which $\mathrm{GH}$ and other cytokines that activate members of the Janus kinase (JAK) family of tyrosine kinases have been shown to regulate gene transcription involves STAT proteins (Figure 1). STAT proteins, originally identified in IFN signaling pathways (Darnell et al., 1994), are latent, SH2-domain containing, cytoplasmic factors. Upon tyrosyl phosphorylation, often via a JAK kinase initiated cascade, cytoplasmic STAT proteins complex with other STAT proteins via an $\mathrm{SH} 2$ domainphosphorylated tyrosine interaction, translocate to the nucleus, bind to DNA and activate transcription of target genes (Ihle, 1996). $\mathrm{GH}$ has been shown to activate STATs 1, 3, 5A and 5B (Figures 1 and Figure 2). GH-dependent tyrosyl phosphorylation of STATs $1,3,5 \mathrm{~A}$ and $5 \mathrm{~B}$ has been observed in 3T3-F442A fibroblasts, liver from hypophysectomized rats, cultured liver cells and in a variety of overexpression systems. Tyrosyl phosphorylation of STATs 5A and 5B has also been observed in human IM-9 cells and liver and skeletal muscle from normal rats (reviewed in Smit et al., 1999).

STAT1, also referred to as p91, was originally identified as a member of the IFN-stimulated gene factor 3 complex that initiates transcription of IFN $\alpha$ stimulated genes (Fu, 1992; Kessler et al., 1990; Shuai et al., 1992). STAT3 was originally identified as acute phase response factor (APRF) that mediates transcriptional regulation of a subset of acute phase response proteins in response to IL-6 (Raz et al., 1994; Wegenka et al., 1994; Zhong et al., 1994). STAT5, or mammary gland factor (MGF), was discovered initially as a PRLinduced transcription factor (Wakao et al., 1994). While a single STAT5 gene was initially identified in sheep, two forms of STAT5 (STAT5A and STAT5B), encoded by two different genes, have now been identified in mouse, human and rat cells (Hou et al., 1995; Kazansky et al., 1995; Lin et al., 1996; Liu et al., 1995; Mui et al., 1995; Ripperger et al., 1995; Silva et al., 1996). The genes encoding STAT5A and STAT5B are highly homologous, being $\sim 90 \%$ identical in coding sequence. They diverge primarily in their $\mathrm{COOH}$-terminal transcription activation domains (Moriggl et al., 1996), exhibit differences in their 


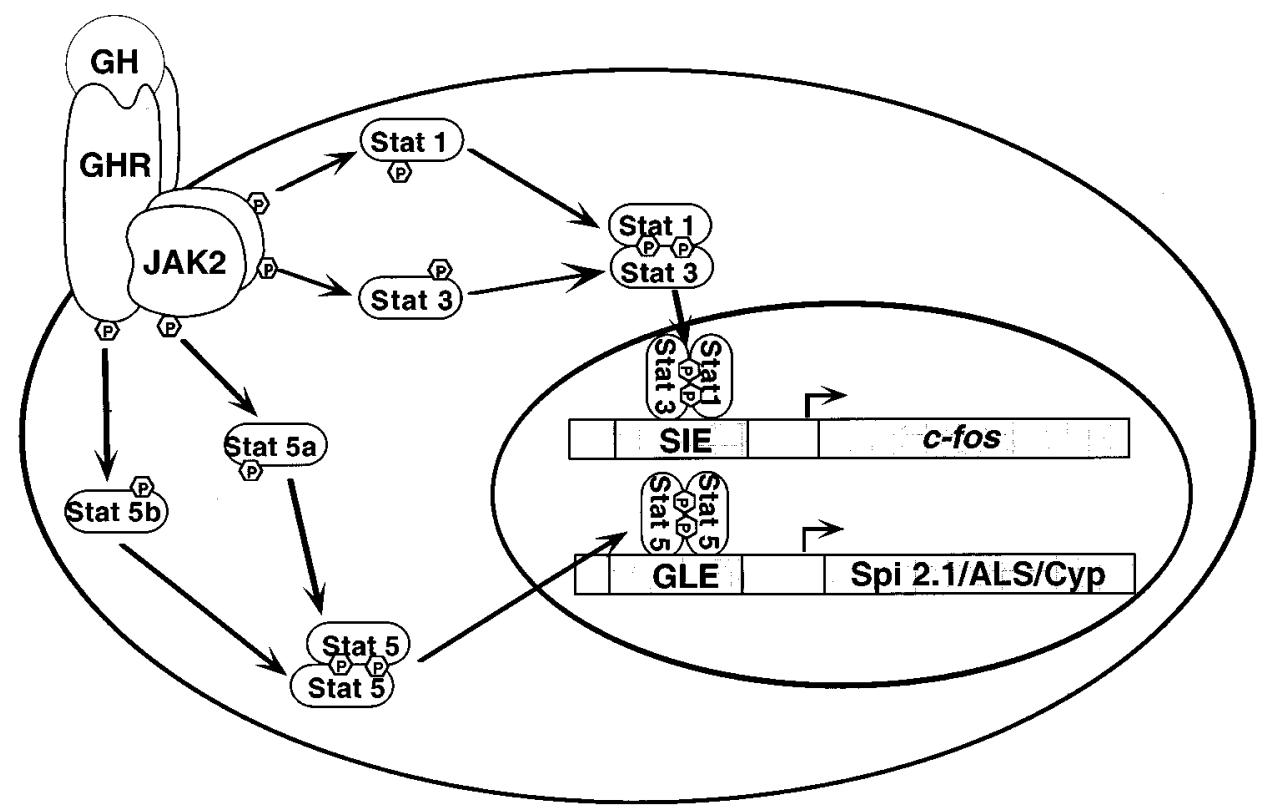

Figure 1 Growth hormone receptor (GHR) signaling via STAT proteins. P, phosphotyrosines; JAK, Janus kinase; SIE, Sisinducible element; GLE, interferon- $\gamma$ activated sequence-like element; Spi, serine protease inhibitor; ALS, acid labile subunit; Cyp, cytochrome P450. (Adapted with permission from Smit L, Meyer D, Argetsinger LS, Schwartz J and Carter-Su C. Handbook of Physiology, Oxford University Press: New York, NY. Vol 5. Eds: JL Kostyo and HM Goodman, pp 445-480, 1999)
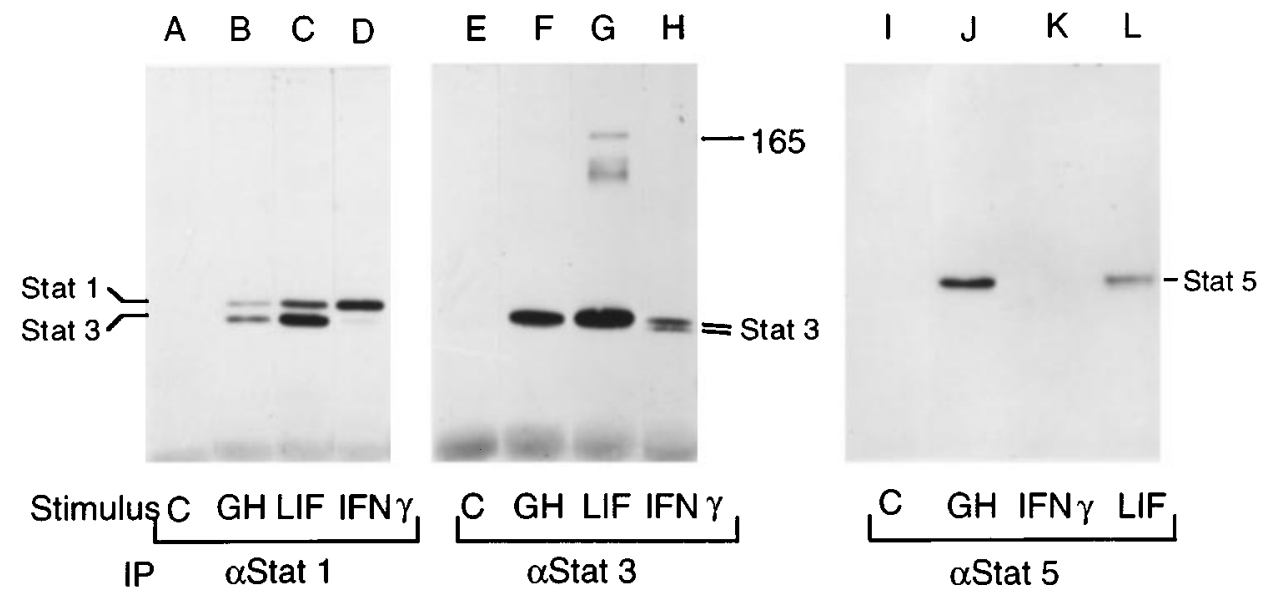

Figure 2 Growth hormone (GH), leukemia-inhibitory factor (LIF), and interferon- $\gamma$ (IFN) induce tyrosyl phosphorylation of STAT1, STAT3, and STAT5 in 3T3-F442A fibroblasts. 3T3-F442A fibroblasts were incubated for $15 \mathrm{~min}$ in the absence of hormone or with $500 \mathrm{ng} / \mathrm{ml}$ human $\mathrm{GH}, 25 \mathrm{ng} / \mathrm{ml}$ human LIF or $10 \mathrm{ng} / \mathrm{ml}$ murine IFN $\gamma$. Whole cell lysates were immunoprecipitated with antibodies to STAT1 $(\alpha$ STAT1), STAT3 $(\alpha$ STAT3) or STAT5 $(\alpha$ STAT5), as indicated. Immunoprecipitated proteins were subjected to Western blot analysis using anti-phosphotyrosine antibody. Migrations of STAT1, STAT3, and STAT5 are indicated. (Reprinted with permission from Carter-Su C, King APJ, Smit LS, VanderKuur JA, Argetsinger LS, Campbell GS. and Huo WJ Anim. Sci. 75 (Suppl. 2), 1-10, 1997)

DNA binding specificities (Boucheron et al., 1998; Verdier et al., 1998) and exhibit differences with respect to their tissue distribution (Liu et al., 1995; Mui et al., 1995). Thus, STAT5A and STAT5B are predicted to have both overlapping and distinct functions with respect to their role in $\mathrm{GH}$ signaling. Based upon the phenotype observed in mice with targeted disruption of their STAT5A versus STAT5B gene, STAT5A and STAT5B appear to have some overlapping functions. However, these same mice exhibit some differences in their phenotype and gene expression pattern, indicating that STAT5A and STAT5B also have distinct roles (Liu et al., 1997, 1998; Park et al., 1999; Teglund et al., 1998; Udy et al., 1997). The observation that a STAT5A-specific antibody immunoprecipitates some
STAT5B in lysates from GH-treated 3T3-F442A fibroblasts and vice versa suggests that STAT5A and STAT5B form heterodimers in response to GH (Smit et al., 1997). Electrophoretic mobility shift assays using the STAT5 response element of the rat $\beta$-casein promoter and liver homogenates from mice with or without targeted disruption of the STAT5A or STAT5B gene also suggest the existence of STAT5A/ STAT5B heterodimers (Park et al., 1999). Heterodimerization of STAT5A and STAT5B in murine mammary gland in response to prolactin has been reported and appears to vary during mammary gland differentiation, suggesting that STAT5A/5B heterodimers have distinct functions from the respective homodimers (Liu et al., 1996). 
Understanding the mechanism by which STAT proteins become phosphorylated, are stimulated to bind to DNA, and regulate gene transcription is critical for understanding $\mathrm{GH}$-regulated gene transcription by the STAT proteins. Analyses of GH signaling in a JAK2 deficient cell line and in several cell lines expressing truncated and mutated $\mathrm{GH}$ receptors indicate that GH-dependent activation of STATs 1, 3, 5A and 5B requires JAK2 activation (Hackett et al., 1995; Han et al., 1996; Smit et al., 1996, 1997; Wang and Wood, 1995). This is consistent with similar findings that activation of JAKs is required for STAT activation by other ligands that bind to cytokine family receptors (Muller et al., 1993; Watling et al., 1993). These findings suggest that JAKs are responsible for tyrosyl phosphorylating STAT proteins. Consistent with this hypothesis, constitutively active overexpressed JAK1 or JAK2 in COS cells stimulates STAT1 DNA binding activity (Silvennoinen et al., 1993) and coexpression of constitutively active JAK 1 , JAK 2 or tyk2 with STAT3 in human kidney fibroblast 293 cells activates STAT3 (Raz et al., 1994). JAK1, JAK2 or tyk2 immunoprecipitates from Sf9 cells infected with virus expressing the respective JAK kinase similarly activate STAT1 (Quelle et al., 1995) and in vitrotranscribed and translated ovine STAT5 is able to bind DNA upon incubation with purified JAK2 and ATP (Gouilleux et al., 1994).

Although JAK2 activation appears to be sufficient for STAT phosphorylation and DNA binding activity when JAK2 and the STATs are overexpressed or in an in vitro setting, it does not appear to be sufficient for activation of STAT5 in intact cells. The current evidence suggests that STAT5 activation by $\mathrm{GH}$ requires phosphorylation of specific tyrosine residues within the $\mathrm{GH}$ receptor, thereby providing a high affinity binding site for the $\mathrm{SH} 2$ domain in the STAT proteins. Specific tyrosines in porcine $\mathrm{GH}$ receptor (Y534, Y566 and Y627, equivalent to Y534, Y566 and Y626 in rat $\mathrm{GH}$ receptor) have been identified as being required for GH-dependent tyrosyl phosphorylation of STAT5 and transcription of the Spi 2.1 promoter (Hansen et al., 1996; Wang et al., 1996). An additional tyrosine (487) has also been suggested as being required for tyrosyl phosphorylation of STAT5 (Wang et al., 1996). In addition to these tyrosines in the Cterminal half of the cytoplasmic domain of $\mathrm{GH}$ receptor, tyrosines 333 and/or 338 in the $\mathrm{N}$-terminal half of the cytoplasmic domain of rat $\mathrm{GH}$ receptor may also play a role in $\mathrm{GH}$-dependent activation of STATs 5A and 5B (Smit et al., 1996, 1997). Association of STAT5 with GH receptor has been detected in 3T3-F442A fibroblasts and in $\mathrm{L}$ cells transfected with $\mathrm{GH}$ receptor and STAT5A cDNAs (Xu et al., 1996). Experiments with GST-GH receptor fusion proteins have suggested that sheep STAT5 and murine STAT5B associate with the C-terminal half of the cytoplasmic domain of $\mathrm{GH}$ receptor and the association is enhanced by phosphorylation of the GH receptor fusion protein (Sotiropoulos et al., 1996; Yi et al., 1996). However, in these experiments the GH receptor fusion proteins are phosphorylated in bacteria by a kinase other than JAK2 and it is not clear whether the phosphorylated tyrosines are the same as those phosphorylated by JAK2. These results suggest that GH-dependent activation of STAT5 proteins requires binding of the STAT to one or more phosphorylated tyrosines in the cytoplasmic domain of $\mathrm{GH}$ receptor. A similar requirement of multiple phosphorylated tyrosine(s) in the receptor for maximal activation of STAT5 has been demonstrated for EPO, PRL, IL-2, IL-5 and granulocyte-macrophage colonystimulating factor (Damen et al., 1995; Fujii et al., 1995; Itoh et al., 1998; Pezet et al., 1997; Quelle et al., 1996; van Dijk et al., 1997).

As observed for GH-dependent activation of STAT5, phosphorylation of specific tyrosines within gp130 and LIF receptor subunits are required for ligand activation of STAT3 (Gerhartz et al., 1996; Stahl et al., 1995). Similarly, specific tyrosine(s) in gp130 and the IFN $\gamma$ receptor are required for ligand-dependent activation of STAT1 (Gerhartz et al., 1996; Greenlund et al., 1994). However, significantly truncated forms of $\mathrm{GH}$ receptor which lack most or all phosphorylated tyrosines can mediate GH-induced tyrosyl phosphorylation of STATs 1 and 3 and binding of STATs 1 and 3 to the Sis inducible element (SIE) of c-fos. This suggests that specific phosphorylated tyrosines in $\mathrm{GH}$ receptor may not be essential for activation of STATs 1 and 3 by GH (Smit et al., 1996; Sotiropoulos et al., 1995, 1996; Wang et al., 1995; Yi et al., 1996). While not essential for $\mathrm{GH}$ dependent activation of STATs 1 and 3, phosphorylated tyrosine(s) in the N-terminal half of the cytoplasmic domain of the rat $\mathrm{GH}$ receptor may contribute to maximal activation of STATs 1 and 3 in response to GH (Smit et al., 1996). A lack of a requirement of phosphorylated tyrosines in $\mathrm{GH}$ receptor for $\mathrm{GH}$ dependent activation of STATs 1 and 3 would be consistent with the absence in $\mathrm{GH}$ receptor of the STAT3 (YXXQ) or STAT1 (YXPQ or YDXXH) association motifs found in gp130, LIF $\beta$ and/or IFN $\gamma$ receptor subunits (Gerhartz et al., 1996; Greenlund et al., 1994; Stahl et al., 1995). In contrast, JAK2 contains two STAT3 association motifs and a STAT1-like association motif. Thus, for $\mathrm{GH}$ which is an extremely effective activator of JAK2 (Argetsinger et al., 1993, 1995), JAK2 may both provide a high affinity binding site for STAT1 and STAT3 and phosphorylate STATs 1 and 3. Alternatively, GH may utilize an intermediary protein in STAT activation, a region of the $\mathrm{GH}$ receptor other than a phosphorylated tyrosine, or a region of JAK2 other than a phosphorylated tyrosine. In support of activation of some STATs being a consequence of their binding directly to JAKs, the activation of STAT5 via gp130 receptor subunit does not need any phosphotyrosines on gp130 but instead STAT5 appears to bind directly to JAKs 1, 2 or 3 (Fujitani et al., 1997). It is also important to note that these conclusions are primarily based on mutagenesis studies which are always subject to the caveat that a mutation may simply alter the conformation of $\mathrm{GH}$ receptor.

Tyrosyl phosphorylation is required for activation of STAT DNA binding activity (Gouilleux et al., 1994; Shuai et al., 1993). However, recent studies have demonstrated that serine phosphorylation also plays a role in activation or regulation of STAT proteins. The observation that multiple tyrosyl phosphorylated STAT3 and STAT5 bands are observed in response to GH in Western blots (Campbell et al., 1995; Ram et al., 1996; Smit et al., 1996, 1997), despite the fact that a single tyrosyl phosphorylation site has been identified in these proteins, suggests that these STAT proteins may be 
phosphorylated on serine residues as well as tyrosine residues. Treatment of $\mathrm{GH}$-activated liver nuclear extracts with either the serine/threonine phosphate specific phosphatase, PP2A, or the tyrosine phosphate specific phosphatase, PTP-1B, results in conversion of slower migrating forms of STAT3 and STAT5 bands to faster migrating forms, suggesting that STAT3 and STAT5 undergo both tyrosyl and seryl and/or threonyl phosphorylation following GH treatment (Ram et al., 1996). The existence of multiple STAT5A and 5B bands in the absence of GH (Smit et al., 1997), suggests that STATs may be seryl and/or threonyl phosphorylated in the absence of ligand. Further evidence for the role of seryl phosphorylation in STAT activation derives from studies with other cytokines and factors. Seryl phosphorylation of STAT1, STAT3 and/or STAT5 in response to IFN $\gamma$, IL-6, IL-2 or insulin has been demonstrated directly by phosphoamino acid analysis (Beadling et al., 1996; Ceresa and Pessin, 1996; Eilers et al., 1995; Wen et al., 1995; Zhang et al., 1995), and it appears to be required for maximal activation of transcription of at least some target genes (Beadling et al., 1996; Wen et al., 1995). Whether it affects DNA binding is controversial. Indirect studies suggest that GH stimulates phosphorylation of STATs 1,3 and 5 on serine or threonine in liver. This phosphorylation enhances the DNA binding of STAT1 and STAT3 and substantially alters the DNA binding of STAT5 (Ram et al., 1996). STATs 1,3 and 5A contain a conserved consensus sequence for phosphorylation by MAP kinase and initial studies suggested that MAP kinase might be responsible for seryl phosphorylation of STAT1. A STAT1-derived peptide was able to serve as a substrate for MAP kinase (Wen et al., 1995) and expression of a dominant negative MAP kinase was reported to inhibit IFN $\gamma$-induced transcription by STAT1 (David et al., 1995). Experiments using the MEK inhibitor PD98059 and STAT5A with a mutated MAP kinase phosphorylation site support the hypothesis that MAP kinases phosphorylate STAT5A and that this phosphorylation is required for full $\mathrm{GH}$-induced activation of STAT5A (Pircher et al., 1997). In contrast, if STAT5B is seryl and/ or threonyl phosphorylated in response to $\mathrm{GH}$, it is likely to be by a kinase other than MAP kinase since the conserved seryl residue found within the consensus site for phosphorylation by MAP kinase in other STAT family members is not present in STAT5B. Interestingly, the MAP kinase pathway is not required for lactogeninduced tyrosyl phosphorylation of STAT5A or STAT5B in mammary epithelial cells or transcriptional activation of a $\beta$-casein reporter construct, as evidenced by the lack of an effect of the MEK inhibitor, PD98059, on these events (Wartmann et al., 1996). In mammary epithelial cells $\mathrm{PKC} \alpha$ and casein kinase II have been implicated in the regulation of STAT5 by prolactin (Marte et al., 1994; Schmitt-Ney et al., 1992). STATs 1, 3, 5A and 5B contain multiple consensus sites for phosphorylation by protein kinase $\mathrm{C}$ and casein kinase. Thus, multiple signaling pathways may converge on STAT proteins and contribute to transcriptional activation by $\mathrm{GH}$.

\section{Nuclear localization of STAT proteins}

While significant work has accumulated regarding the mechanism of activation of STAT proteins by GH and other cytokines, the mechanisms regulating the cellular distribution of STAT proteins remain poorly understood. It is well documented that in response to $\mathrm{GH}$, STAT proteins undergo a rapid, dramatic accumulation in the nucleus (Figure 3), yet they lack a conventional nuclear localization signal and are too big to diffuse through nuclear pores. Data is emerging on the mechanisms regulating STAT localization in response to ligands other than $\mathrm{GH}$, that might eventually prove applicable to STAT localization in response to GH. For example, IFN- $\gamma$-stimulated STAT1 nuclear import requires the importin $\alpha / \beta$ and RAN/TC4 pathway (Sekimoto et al., 1996, 1997). However, STAT1 lacks a conventional nuclear localization sequence, the stretch of basic amino acids that bind importin $\alpha$. Yet STAT1 dimers can associate with NPI-1, an importin- $\alpha$ homologue (Sekimoto et al., 1997). Nuclear localization of STAT1 in response to cytokines requires the amino-terminus of Stat1 (Strehlow and Schindler, 1998). Hence, it is possible that dimers of the amino-terminus of STAT1 create the structure required for binding to nuclear import
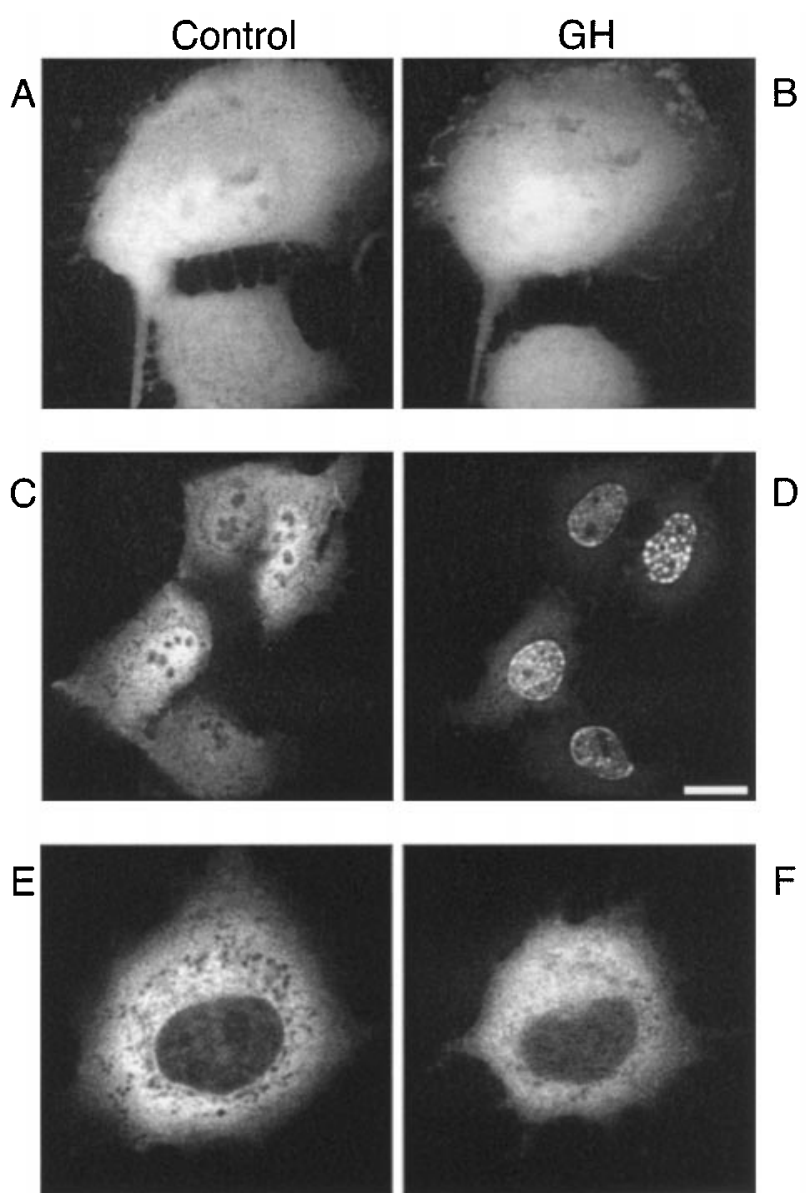

Figure $3 \mathrm{GH}$ promotes nuclear localization of GFP-STAT5B. $\mathrm{A}-\mathrm{F}, 2 \mathrm{C} 4$ cells were transfected with cDNA expression vectors $(3 \mu \mathrm{g})$ for either GHR and GFP (a and b), GHR and GFPSTAT5B (c and d), or GHR and DNA binding domain mutant GFP-STAT5B $\mathrm{VVVI}$ (amino acids ${ }^{466} \mathrm{VVVI}^{469}$ to alanine; $6 \mu \mathrm{g}$, e and $\mathbf{f}$ ). Cells were imaged by laser scanning confocal microscopy prior to (a, c, and e) and following (b, d and f) 40-60 min treatment with $500 \mathrm{ng} / \mathrm{ml} \mathrm{GH}$. Images a, c, and e are of the same cell as b, d, and $\mathbf{f}$, respectively. Scale bar (d) represents $15 \mu \mathrm{m}$ for $\mathbf{a}-\mathbf{d}$ and $8 \mu \mathrm{m}$ for $\mathbf{e}$ and $\mathbf{f}$. (Reprinted in modified form with permission from Herrington J, Rui L, Luo G, Yu-Lee L and Carter-Su C. J. Biol. Chem., 274, 5138-5145, 1999) 
proteins. Alternatively, other proteins that associate with STATs may serve as chaperones for STAT entry into the nucleus. Ligand/receptor complexes have recently been suggested as candidates for this role (Johnson et al., 1998a,b). Interestingly, PRL-induced nuclear localization, but not tyrosyl phosphorylation, of STAT5 is inhibited by mutation of tyrosine 382 in the cytoplasmic domain of the PRL receptor (Ali and Ali, 1998). Green fluorescent protein (GFP)-STAT5B in conjunction with laser scanning confocal imaging revealed that a mutation that prevents binding of STAT5B to DNA $\left({ }^{466} \mathrm{VVVI}^{469}\right)$ abrogates GH-stimulated nuclear localization (Figure 3). This mutant fusion protein was tyrosyl phosphorylated and dimerized in response to $\mathrm{GH}$ (Herrington et al., 1999). This suggests that either high affinity binding to DNA contributes to nuclear accumulation of STAT5B or that this region is crucial for two functions, namely accumulation of STAT5B in the nucleus and DNA binding.

\section{Activation of STAT phosphorylation by SH2-B $\beta$}

Because activation of STAT proteins is highly dependent upon the activity of JAK and the number of phosphorylated tyrosines within cytokine receptor JAK complexes, it is clear that proteins that regulate JAK activity would also regulate STAT activation. One such protein that regulates the activity of JAK2 is the $\mathrm{SH} 2$ domain containing protein $\mathrm{SH} 2-\mathrm{B} \beta$ (Figure 4). $\mathrm{SH} 2-\mathrm{B} \beta$ was initially identified as a JAK2interacting protein that is tyrosyl phosphorylated in response to $\mathrm{GH}$ and other cytokines that activate JAK2 (Rui et al., 1997). While the structure of SH2$\mathrm{B} \beta$ suggested that it was likely to serve as an adapter protein for JAK2, it has recently been shown to be a potent activator of JAK2 (Rui and Carter-Su, 1999).
Consistent with this activation role, overexpression of wild-type $\mathrm{SH} 2-\mathrm{B} \beta$ has been shown to greatly enhance the ability of $\mathrm{GH}$ to stimulate the tyrosyl phosphorylation of STAT3 and STAT5B (Rui and Carter-Su, 1999) (Figure 5). In addition, mutating the critical lysine in the FLVR domain of $\mathrm{SH} 2-\mathrm{B} \beta$, which prevents activation of $\mathrm{JAK} 2$ by $\mathrm{SH} 2-\mathrm{B} \beta$, also inhibits the ability of STAT5B to migrate to the nucleus (Herrington et al., 2000).

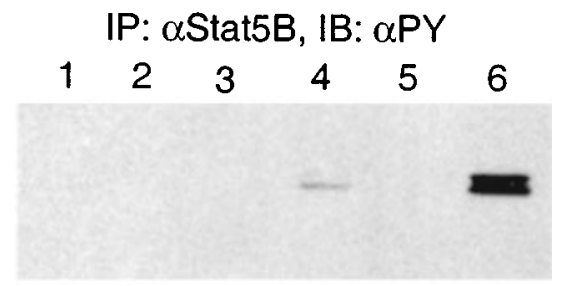

IB: $\alpha$ Stat5B

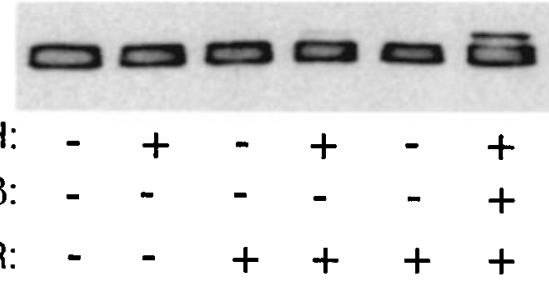

Figure $5 \mathrm{SH} 2-\mathrm{B} \beta$ enhances $\mathrm{GH}$-induced tyrosyl phosphorylation of STAT5B. COS cells were co-transfected with plasmids encoding $\mathrm{GH}$ receptor (GHR), STAT5B, and $\mathrm{SH} 2-\mathrm{B} \beta$ as indicated. Twenty-four hours after transfection, cells were deprived of serum overnight and treated with $50 \mathrm{ng} / \mathrm{ml} \mathrm{GH}$ for $15 \mathrm{~min}$. STAT5B was immunoprecipitated with $\alpha$ STAT5B, immunoblotted with $\alpha \mathrm{PY}$ (upper panel), and reprobed with $\alpha$ STAT5B (lower panel). (Reprinted in modified form with permission from Rui L and Carter-Su C. Proc. Natl. Acad. Sci. USA, 96, 7172-7177, 1999)

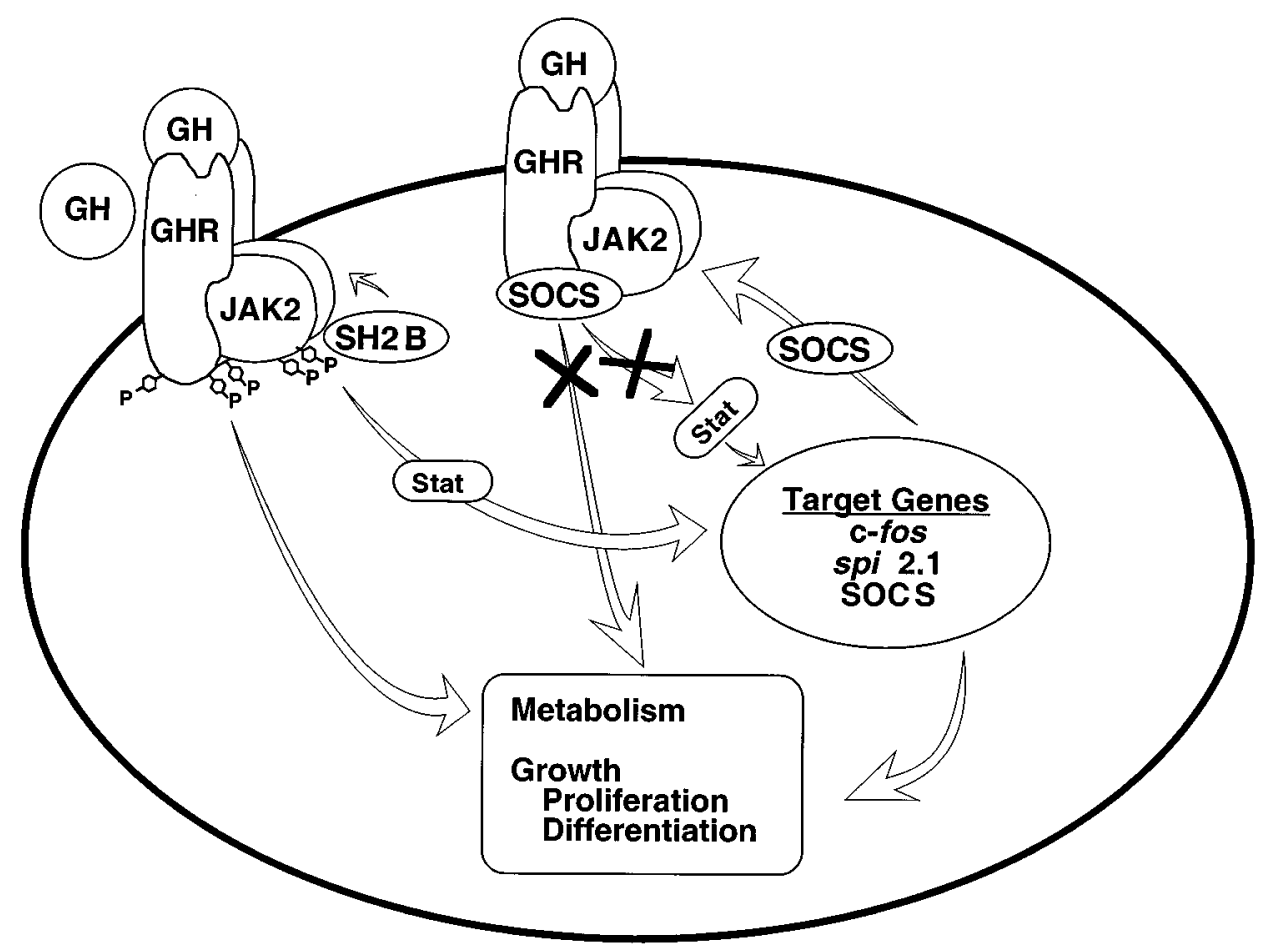

Figure 4 Regulation of STATs by SH2-B and SOCs family members. P, phosphotyrosines; JAK, Janus kinase; Spi, serine protease inhibitor; SOCS, suppressor of cytokine signaling 
The role of tyrosine phosphatases in the termination of GH-activated STAT signaling

Termination of GH-activated STAT signaling is thought to involve at least two types of signaling events: dephosphorylation of tyrosines in GHR, JAK2 and STATs by phosphatases and expression of the suppressors of cytokine signaling (SOCS) family of proteins. Termination of GH-activated STAT signaling presumably involves activation and/or recruitment of a protein tyrosine phosphatase to GHR/JAK2 signaling complexes. This phosphatase would dephosphorylate GHR, JAK2, or the STATs themselves to downregulate signaling. Since STATs are generally thought to require phosphorylated GHR for docking and subsequent activation by JAK2, dephosphorylation of GHR would be expected to terminate further STAT activation. Dephosphorylation of GHR may also signal its internalization and degradation (Gebert et al., 1999a,b). Dephosphorylation of the critical activating tyrosine within the kinase domain of JAK2 would be expected to deactivate JAK2 whereas dephosphorylation of the tyrosine in STAT critical for dimerization and high affinity DNA binding would also effectively terminate further signaling. Indeed, termination of activated STAT5B is thought to involve dephosphorylation of JAK2 and STAT5B (Gebert et al., 1997, 1999a).

The phosphatase(s) responsible for the above dephosphorylation events are unknown. Two candidate phosphatases that might serve as negative regulators of $\mathrm{GH}$-activated signaling are the $\mathrm{SH} 2$ domain-containing phosphatases SHP-1 and SHP-2 (Feng et al., 1993). SHP-1 has been demonstrated to negatively regulate JAK/STAT signaling mediated by the various cytokine receptors in hematopoietic cells (David et al., 1996; Haque et al., 1998; Klingmuller et al., 1995; Yi et al., 1993). SHP-1 directly associates with JAK2 (Jiao et al., 1996) and SHP-1 has been suggested to play a role in the dephosphorylation of JAK2 in liver in response to GH (Hackett et al., 1997). Both SHP-1 and SHP-2 have been suggested as potential phosphatases for Stat5 (Ram and Waxman, 1997; Yu et al., 2000). SHP-2 associates with GHR in response to GH (Kim et al., 1998; Stofega et al., 1998) and mutation of tyrosine residues in GHR that serve as binding sites for SHP-2 prolong tyrosyl phosphorylation of GHR, JAK2 and STAT5B in response to GH (Stofega et al., 2000).

Other phosphatases are also likely involved in dephosphorylating GHR, JAK2 and STATs. For example, deactivation of JAK2 is slowed by the non-specific, serine/threonine kinase inhibitor $\mathrm{H}-7$ and by the protein synthesis inhibitor, cyclohexamide (Fernandez et al., 1998; Gebert et al., 1999a). Hence, it has been suggested that deactivation of JAK2 may occur by the serine/threonine kinase-dependent expression of a tyrosine phosphatase (Gebert et al., 1999a).

\section{The role of SOCS proteins in the termination of $\mathrm{GH}$ - activated STAT signaling}

SOCS proteins constitute a negative feedback loop within the cell: their expression is induced by cytokines and hormones and they act to inhibit further signaling of the activated receptor complexes (Endo et al., 1997;
Naka et al., 1997; Starr et al., 1997) (Figure 4). GH induces expression of SOCS-1, -2, -3 and CIS in rat liver to varying degrees and with different kinetics (Adams et al., 1998; Ram and Waxman, 1999; TolletEgnell et al., 1999). The signaling pathways involved in induction of SOCS expression in response to $\mathrm{GH}$ remain to be fully characterized, but are predicted to require STAT signaling (Naka et al., 1997). In the case of SOCS-2 and SOCS-3, STAT5B is thought to mediate $\mathrm{GH}$ induction of their expression in liver (Davey et al., 1999a).

More is known about how SOCS proteins inhibit GH-activated STAT signaling. SOCS-1 is best understood. SOCS-1 can interact directly with all four members of the JAK family (Endo et al., 1997; Naka et al., 1997). SOCS-1 inhibition of JAK2 activity requires interactions between the $\mathrm{SH} 2$ domain of SOCS-1 and the kinase activation loop of JAK2 (Yasukawa et al., 1999). It is thought that a region $\mathrm{N}$-terminal to the $\mathrm{SH} 2$ domain acts as a inhibitory pseudosubstrate of JAK2 (Narazaki et al., 1998; Yasukawa et al., 1999). Consistent with a direct action of SOCS-1 on JAK2 activity, SOCS-1 inhibits tyrosyl phosphorylation of overexpressed JAK2 even when GH receptor is not present (Hansen et al., 1999; Ram and Waxman, 1999). Constitutively expressed SOCS-1 virtually abolishes GH-dependent STAT5B tyrosyl phosphorylation, DNA binding and STAT5-mediated gene expression (Adams et al., 1998; Hansen et al., 1999, Ram and Waxman, 1999). Interestingly SOCS-1 can also bind the cytoplasmic domain of GHR fused to GST, suggesting GHR may direct SOCS-1 to JAK2 (Hansen et al., 1999; Ram and Waxman, 1999).

SOCS-2 action on GH-induced STAT signaling is less clear. Constitutive overexpression of SOCS-2 has been reported to enhance, partially inhibit and have no effect on STAT5-driven gene expression (Adams et al., 1998; Hansen et al., 1999; Karlsson et al., 1999; Ram and Waxman, 1999). Recent studies have suggested that these disparities may be due to different levels of SOCS-2 protein and suggest that, at high levels, SOCS2 may enhance GH signaling by relieving inhibition from more potent, endogenous SOCS molecules (Favre et al., 1999).

SOCS-3 is rapidly and prominently induced in liver by GH (Adams et al., 1998; Tollet-Egnell et al., 1999), suggesting it may have a prominent role in the termination of STAT signaling. In contrast to SOCS1, SOCS-3 inhibits JAK2 by a mechanism requiring GHR (Hansen et al., 1999). The mechanism by which this occurs, however, is unclear. Studies using the cytoplasmic domain of GHR tyrosyl phosphorylated in bacteria by kinases other than JAK2 have shown that SOCS-3, as well as the other GH-regulated SOCSs, can bind directly to GHR. However, attempts at identifying the regions and specific tyrosines required in GHR using truncated and mutated GHR fusion proteins have yielded conflicting answers (Hansen et al., 1999; Ram and Waxman, 1999). These studies highlight the necessity of using GHR phosphorylated by JAK2 to determine the mechanism of JAK2 inhibition by SOCSs that require GHR.

CIS, like SOCS-3, is prominently induced in liver by GH (Adams et al., 1998; Tollet-Egnell et al., 1999; Ram and Waxman, 1999) and appears to also require GHR to inhibit JAK2 (Ram and Waxman, 1999). CIS 
is known to associate with tyrosyl phosphorylated interleukin-3B and erythropoietin receptors (Yoshimura et al., 1995). Consistent with an important physiological role of CIS in GH signaling, transgenic mice constitutively expressing CIS have reduced body weight and lower major urinary protein (MUP) levels in their urine (Matsumoto et al., 1999), characteristics of mice deficient in Stat5.

\section{The role of STAT5 in GH-mediated gene expression}

STAT5a and STAT5b have been strongly implicated in GH signaling through their participation in transcriptional activation of multiple $\mathrm{GH}$-regulated genes. $\mathrm{GH}$ induces the binding of STAT5 proteins to IFN $\gamma$ activated sequence (GAS)-like elements (GLE) in several different genes, including the GH-sensitive spi 2.1, Insulin 1 and p450 CYP3A 6 beta-hydroxylase genes (Bergad et al., 1995; Galsgaard et al., 1996; Hansen et al., 1996; Subramanian et al., 1995; Wood et al., 1995). STAT5 mediates GH-dependent transcriptional activation of promoter-reporter constructs containing the STAT5-binding promoter elements of these genes (Bergad et al., 1995; Galsgaard et al., 1996; Hansen et al., 1996; Sotiropoulos et al., 1996; Subramanian et al., 1995; Wood et al., 1995).

\section{STAT5 involvement in the expression of serine protease Inhibitor 2.1}

The role of STAT5 in GH regulated gene transcription has been elucidated in particular detail by analysis of the gene encoding the serine protease inhibitor Spi 2.1. The expression of liver-specific spi 2.1 is tightly controlled by $\mathrm{GH}$ at the transcriptional level (LeCam et al., 1987; Paquereau et al., 1992). This GH-regulated gene was originally identified through the screening of rat hepatic cDNA libraries (LeCam et al., 1987; Yoon et al., 1987). Promoter analysis identified a sequence which could confer $\mathrm{GH}$ responsiveness to a heterologous promoter in primary hepatocytes (Yoon et al., 1990). Further analysis revealed two GH Response Elements (GHRE) (Paquereau et al., 1992). A nuclear factor, subsequently identified as STAT5 (Wood et al., 1995), was found to bind synergistically to two GLE sequences (GLE 1 and 2) (Bergad et al., 1995) in the GHRE2. Both GLE 1 and 2 bind STAT5A and 5B in a $\mathrm{GH}$-dependent manner for transcriptional activation (Bergad et al., 1995; Sliva et al., 1994; Wood et al., 1995). A GH-responsive spi 2.1 GLE-containing reporter was used in the evaluation of those regions of the $\mathrm{GH}$ receptor involved in changes in gene expression. These studies demonstrate that the proline-rich region of the $\mathrm{GH}$ receptor required for JAK2 activation is required for spi 2.1 expression (Goujon et $a l ., 1994)$ and that a GH receptor containing any one of five tyrosines in the cytoplasmic domain is sufficient to induce expression of the spi promoter-reporter gene (Enberg et al., 1994).

The physiological regulation of spi 2.1 expression by $\mathrm{GH}$ involves other transcription factors in addition to STAT5. In the spi 2.1 promoter, STAT5 has been shown to associate with the glucocorticoid receptor (GR) and YY1 (Bergad et al., 2000). In addition, five C/EBP sites have been identified in the spi 2.1 promoter (LeCam et al., 1994), one of which coincides with GLE1 and is essential for GH-dependent enhancer function (LeCam et al., 1994). The more downstream GHRE1 of spi 2.1 contains a GAGA sequence which has been shown to be essential for initiating GH-promoted spi 2.1 expression, possibly through chromatin remodeling (Simar-Blanchet et al., 1998). These studies indicate that GH-stimulated transcription of spi 2.1 is complex, and involves STAT5 as well as other proteins.

STAT5 involvement in $G H$ regulation of genes associated with growth and metabolism

STAT5 has recently been shown to contribute to regulation of several components of the GH-insulinlike growth factor 1 (IGF-1) axis, long recognized as fundamental for growth-promoting actions of GH. In the circulation, IGF-1 forms a complex with the Acid Labile Subunit (ALS) and IGF-binding protein 3 (Boisclair et al., 1996; Dai et al., 1994). GH was found to stimulate ALS transcription in a hepatoma cell line (Ooi et al., 1997). A GH-responsive DNA sequence in ALS gene promoter (Boisclair et al., 1996) contains two ALS-GAS sites. STAT5A and STAT5B bind to the ALS-GAS1 in response to $\mathrm{GH}$ and mediate transcriptional activation of the ALS gene (Ooi et al., 1997). Although it is well-recognized that $\mathrm{GH}$ stimulates IGF-1 production and gene expression in liver and other cell types (Bichell et al., 1992; Isgaard et al., 1988; Mathews et al., 1986; Peter et al., 1993), identifying the GH-regulated transcription factors involved has been challenging. Establishment of novel GH-responsive cell lines has facilitated demonstration that STAT5 participates in GH-stimulated expression of IGF-1. STAT5 has been implicated in GHdependent activation of the salmon IGF-1 promoter in Hep3B cells expressing the $\mathrm{GH}$ receptor (Meton et al., 1999). In these cells, the GH-dependent activation of the IGF-1 gene involves a synergistic action of STAT5 and HNF-1 $\alpha$ when they are simultaneously expressed. Similarly, in C6 glioma cells overexpressing $\mathrm{GH}$ receptor and Jak2, GH stimulated reporter expression via the rat IGF-1 promoter. In these cells, GH also activated STATs 1, 3 and 5 (Benbassat et al., 1999), consistent with involvement of STATs in GHregulated IGF-1 gene expression.

In addition to participating in regulation of genes associated with GH-regulated growth, STAT5 also contributes to genes associated with metabolic regulation by $\mathrm{GH}$. GH excess is associated with hyperinsulinemia, and $\mathrm{GH}$ can stimulate expression of the insulin gene in the pancreatic $\beta$-cell line RIN-5AH (Billestrup and Martin, 1985). Such stimulation requires the $\mathrm{C}$-terminal half of the cytoplasmic domain of the $\mathrm{GH}$ receptor and is associated with a $\mathrm{GH}$ induced rise in intracellular calcium (Billestrup et al., 1995; Moldrup et al., 1991). A GH responsive GASlike element in the insulin promoter can bind $\mathrm{GH}$ induced STAT5 and is able to mediate GH-induced gene expression in RIN-5AH cells (Galsgaard et al., 1996).

GH-regulated binding of STAT5 to the GAS-like element in the promoter of the $\beta$-casein gene has also been observed in nuclear extracts from several different cell types (Gouilleux et al., 1995; Han et al., 1996; Ram et al., 1996; Silva et al., 1996; Smit et al., 1996, 1997; 
Tourkine et al., 1995). An initial study reported that $\mathrm{GH}$ failed to induce transcription of a $\beta$-casein promoter-luciferase construct in COS cells transiently transfected with an ovine STAT5 cDNA expression vector (Gouilleux et al., 1995). In a subsequent report, GH was observed to stimulate transcriptional activation of a $\beta$-casein promoter luciferase reporter construct in $\mathrm{CHO}$ and 293 cells transfected with a GH receptor cDNA expression vector (Sotiropoulos et al., 1996), although prolactin, rather than $\mathrm{GH}$ regulates expression of this gene in vivo.

\section{GH-regulated genes utilizing STATs 1 and 3}

Initial evidence implicating STATs in GH action was based on observations that GH induced the phosphorylation and binding of STATs 1 and 3 to the Sisinducible element of c-fos (Campbell et al., 1994; Gronowski and Rotwein, 1994; Gronowski et al., 1995; Meyer et al., 1994). Induction of the binding of STATs 1 and 3 occurred readily in several GH-responsive systems, including 3T3-F442A fibroblasts and liver from hypophysectomized rats treated with $\mathrm{GH}$. Tandem copies of the SIE mediated transcription in response to $\mathrm{GH}$ in COS cells overexpressing GHR and STAT3 (Sotiropoulos et al., 1996). The physiological relevance of STATs 1 and 3 in GH-regulated transcription of c-fos is supported by mutational and deletion analysis of the c-fos enhancer. These studies revealed that the combined presence of the SIE, Serum Response Element (SRE), and an adjacent AP-1 site are required for full induction by $\mathrm{GH}$; progressive deletions of each of these elements led to progressive decreases in reporter expression (Chen et al., 1995). The involvement of multiple regulatory elements in the physiological regulation of c-fos is also suggested by transgenic mouse studies in which mutations in specific regulatory regions (SIE, SRE, AP-1 and Cyclic AMP Response Element) were introduced into fos-promoter/ LacZ constructs. Each of the multiple control elements was found to be required for normal c-fos expression in vivo (Robertson et al., 1995). The SRE also mediates transcription in response to $\mathrm{GH}$, and $\mathrm{GH}$ can increase binding to $\mathrm{C} / \mathrm{EBP}$ and $\mathrm{AP}-1$ sites in c-fos. Whether these GH-regulated sequences, including the SIE, cooperate with each other in GH-promoted c-fos expression remains to be determined. Among other GH-regulated genes utilizing STATs 1 and 3, the promoter of the gene encoding Interferon Regulatory Factor (IRF-1) has been shown to bind STATs 1 and 3 induced in liver by GH treatment of hypophysectomized rats (Le Stunff and Rotwein, 1998). Thus, it is clear that STATs 1,3 and 5 can participate in regulation of multiple genes in response to GH. Such regulation is likely to involve participation of other transcription factors as well as STATs, and to coordinate the expression of multiple GH-responsive genes in a variety of cell types.

\section{Pulsatile GH secretion determines regulation of multiple genes via STAT5}

$\mathrm{GH}$ secretion from the pituitary gland is pulsatile. In many species including rat, chicken and humans the pattern in males is characterized by higher peaks and deeper troughs than in females (Asplin et al., 1989;
Eden et al., 1982; Johnson, 1988; Tannenbaum and Martin, 1976; Winer et al., 1990). The sexually dimorphic pattern of $\mathrm{GH}$ secretion produces distinct differences in the expression of certain genes. Notable among these are hepatic genes of the cytochrome P450 (CYP) family, particularly those in the gene family CYP2 and CYP3 which encode enzymes involved in the metabolism of endogenous steroids and lipophilic compounds (Nebert, 1991; Waxman et al., 1995). The male-specific rat liver P450s include androgen $16 \alpha$ and $2 \alpha$ hydroxylase CYP2C11, the steroid $6 \beta$-hydroxylase CYP3A2, testosterone $15 \alpha$-hydroxylase CYP2A2, and the fatty acid $\omega$-hydroxylase CYP4A2. The gene encoding hamster CYP 3 A $10 / 6 \beta$-hydroxylase has been shown to contain a GAS-like element which binds STAT5 in animals exhibiting a male pattern of pulsatile GH release (Subramanian et al., 1995), indicating the presence of a mechanism dependent on the pulsatile $\mathrm{GH}$ secretion pattern at the level of gene transcription and STAT5. The female-specific steroid sulfate $15 \beta$-hydroxylase CYP2C12 is expressed under conditions of continuous GH secretion (Legraverend et al., 1992; Nebert et al., 1991). Both 2C11 and 2C12 are regulated by $\mathrm{GH}$ at the transcriptional level (Sundseth et al., 1992).

\section{STAT5B is responsive to pulsatile $G H$}

Following a pulse of $\mathrm{GH}$, activation of STAT5B in rat liver is fully restored when a second GH pulse is given $4 \mathrm{~h}$ later. In contrast, activation of STAT1 and STAT3 shows strong desensitization such that $4 \mathrm{~h}$ is not sufficient to restore full responsiveness to $\mathrm{GH}$ (Ram et al., 1996). Thus, STAT5B is unique among the GHactivated STATs in that it is appropriately sensitive to pulsatile $\mathrm{GH}$, suggestive that many of the physiological actions of $\mathrm{GH}$ in males may be mediated in part by STAT5B. Studies of gene expression and body growth using STAT5B-deficient mice have supported this view (Davey et al., 1999c; Teglund et al., 1998; Udy et al., 1997).

Given that STAT5B appears to be important in transducing the actions of pulsatile $\mathrm{GH}$, what are the properties of the $\mathrm{GH}$ signaling cascade that underlie this behavior? Studies on the activation and deactivation cycle of STAT5B in the immortalized rat hepatocyte-derived line, CWSV-1, have provided insight into this question. In general, the activated GHR/ JAK2 complex is thought to possess a longer lifetime than activated STAT5B, such that the active GHR/ JAK 2 complex can initiate multiple STAT5B activation cycles prior to deactivation of GHR/JAK2 (Gebert et al., 1999a). Following a pulse of GH, deactivation of STAT5B as assessed by loss of DNA binding is rapid ( $\sim 30 \mathrm{~min}$ ) and is thought to involve dephosphorylation of STAT5B and deactivation of JAK2 (Gebert et al., 1997, 1999a).

Once STAT5B is deactivated, recovery of full responsiveness to $\mathrm{GH}$ requires approximately 2 more hours (Gebert et al., 1997). The mechanisms involved in resetting STAT5B sensitivity to $\mathrm{GH}$ are less clear. Recovery of full responsiveness does not appear to require new protein synthesis (Gebert et al., 1997). However, the serine/threonine kinase inhibitor $\mathrm{H} 7$ shortens the interpulse interval required for recovery of full responsiveness of STAT5B to GH. The 
mechanism by which $\mathrm{H} 7$ shortens the required interpulse interval is unknown but may involve inhibition of GHR internalization and degradation (Gebert et al., 1999a).

Continuous GH exposure, characteristic of the female pattern of $\mathrm{GH}$ secretion, results in low level activation of JAK2 and STAT5B (approximately 10$20 \%$ of the maximum level induced by a $\mathrm{GH}$ pulse) (Gebert et al., 1999b). The lower level is thought to be due to increased phosphotyrosine phosphatase activity towards GHR/JAK2 and STAT5B. Unlike the case of $\mathrm{GH}$ pulse signaling to STAT5B, cycloheximide eliminates STAT5B activation with continuous $\mathrm{GH}$ exposure. Dephosphorylation of GHR leading to internalization and degradation has been suggested as a cause for the requirement for new protein synthesis (Gebert et al., 1999b).

The physiological importance of STAT5A and STAT5B as determined by knockout studies

STAT knockout mice have provided significant insight into the physiological role of the different STAT proteins. In the case of $\mathrm{GH}$, mice deficient in STAT5A and/or STAT5B have provided the greatest insight into the role of STAT proteins in the actions of $\mathrm{GH}$ as will be discussed below. In contrast, STAT1 and STAT3 knockout studies have been less informative. The absence of STAT3 results in embryonic lethality (Takeda et al., 1997), thus it is not possible to use STAT3 knockout mice to gain insight into the role of STAT3 in GH actions. The STAT1 deficient mice are not small (Durbin et al., 1996; Meraz et al., 1996), suggesting that STAT1 may not be a major determinant of body growth. Whether it plays a role in other actions of $\mathrm{GH}$ has not been investigated.

When STAT5A-deficient mice were generated, STAT5A was found to be required for mammary gland development and lactogenesis, two processes mediated by PRL. No effect on body growth was noted (Liu et al., 1997). A second group has confirmed and extended these observations (Teglund et al., 1998). Body growth, serum IGF-1 levels, and expression of GH-regulated genes were not altered in STAT5Adeficient mice of either sex (Teglund et al., 1998). These results suggest that Stat5A plays a minor role in $\mathrm{GH}$ regulated processes or that loss of STAT5A can easily be compensated by other factors, most notably STAT5B.

In striking contrast, mice deficient in STAT5B have pronounced impairment of body growth, especially in males (Teglund et al., 1998; Udy et al., 1997) (Figure 6). Male STAT5B-deficient mice grow at a rate similar to normal females (Udy et al., 1997). Serum IGF-1 levels are reduced in males but not females (Teglund et al., 1998). Expression of the testosterone 16 $\alpha$-hydroxylase CYP2D9, normally expressed higher in males, is reduced to female levels in STAT5B-deficient male mice (Teglund et al., 1998; Udy et al., 1997). In contrast, testosterone $15 \alpha$-hydroxylase CYP2A4, normally repressed in males, is increased in STAT5Bdeficient male mice to female levels (Teglund et al. 1998; Udy et al., 1997). Thus, STAT5B appears to be of major importance in transducing the sexual dimorphic pattern of $\mathrm{GH}$ secretion into sex-specific patterns of liver gene expression and body growth.

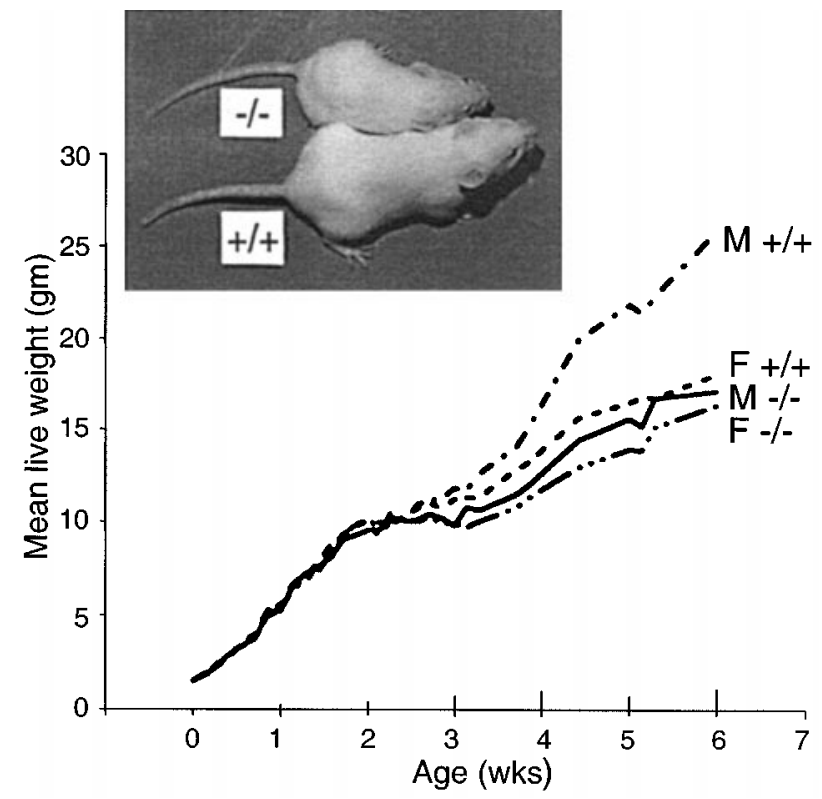

Figure 6 STAT5B is required for male pattern growth. Body weights of wild-type males were significantly different from STAT5B $-/-$ males $(\mathrm{M})$ and females $(\mathrm{F}) \quad(P<0.001)$. No significant differences were seen between STAT5B $-/-$ males, wild-type females, and STAT5B $-/-$ females. (Reprinted in modified form with permission from Udy GB, Towers R, Snell RG, Wilkins RJ, Park S-H, Ram PA, Waxman DJ and Davey HW. Proc. Natl. Acad. Sci. USA, 94, 7239-7244, 1997)

Studies comparing liver gene expression in hypophysectomized normal and STAT5B-deficient mice given $\mathrm{GH}$ pulse replacement support this idea (Davey et al., 1999b).

Given these data it is tempting to think of STAT5A as a female-specific mediator of PRL action and STAT5B as a male-specific mediator of GH action. Such categorization is likely an over-simplification for several reasons. STAT5B deficiency in females alters both liver gene expression and body growth, albeit modestly (Teglund et al., 1998; Udy et al., 1997). Deletion of STAT5A and STAT5B together supports the view for redundancy in function of these proteins in $\mathrm{GH}$ action. The most severe defects in liver gene expression and body growth, affecting both sexes, are found when mice lack both STAT5A and STAT5B (Teglund et al., 1998). Thus, both STAT5A and STAT5B, acting in concert, are apparently required for normal $\mathrm{GH}$-dependent growth.

The establishment of mice deficient in the STAT5 proteins has led to the rapid advancement of our understanding of STAT5 signaling in GH physiology. In addition to body growth and liver gene transcription, STAT5B is reported to be involved in the lipolytic action of GH on adipose tissue (Fain et al., 1999). Yet other GH signaling molecules are likely to play similarly important roles. Hypophysectomized STAT5B-deficient male mice given GH pulse replacement suggest that STAT5B is required for pulsatile GH-driven growth (Davey et al., 1999b). However, male and female mice deficient in STAT5A and STAT5B either alone or in combination still grow, although significantly slower than normal. Whether this growth is GH-dependent awaits further studies. Also, STAT5 proteins appear not to be required for the insulin-like action of $\mathrm{GH}$ on glucose metabolism 
and leptin release (Fain et al., 1999). Importantly, STATs have been shown to be regulated by $\mathrm{GH}$ in normal human fibroblasts and to be altered in cells from Laron Syndrome patients (Freeth et al., 1998).

\section{Summary and conclusions}

It is clear that STATs are key contributors to $\mathrm{GH}$ signaling and to the mechanisms by which $\mathrm{GH}$ activates genes that lead to its physiological actions. STATs 1,3 and 5 are tightly regulated by GH-GHRJAK2 interactions, and participate in the regulation of many genes, including genes associated with growth and metabolic effects of GH. Studies using knockout mice have substantiated a role for STATs 5A and 5B in $\mathrm{GH}$-dependent growth regulation. It is notable that
STAT5B appears to mediate the complex regulation of sexually dimorphic gene expression by 'interpreting' the $\mathrm{GH}$ secretion pattern in males $v s$ females. Further understanding of the versatile roles of STATs in GH signaling and regulation of gene expression will add to our understanding of the multiple physiological actions of $\mathrm{GH}$.

\section{Acknowledgments}

We gratefully acknowledge the assistance of B Hawkins and $\mathrm{K}$ O'Brien with the figures and manuscript preparation. This work was supported in part by NIH grants RO1DK34171 (to C Carter-Su and J Schwartz), RO1-DK54222 (to C Carter-Su) and RO1-DK46072 (to J Schwartz).

\section{References}

Adams TE, Hansen JA, Starr R, Nicola NA, Hilton DJ and Billestrup N. (1998). J. Biol. Chem., 273, 1285-1287.

Ali S and Ali S. (1998). J. Biol. Chem., 273, 7709-7716.

Argetsinger LS, Campbell GS, Yang X, Witthuhn BA, Silvennoinen O, Ihle JN and Carter-Su C. (1993). Cell, 74, $237-244$.

Argetsinger LS, Hsu GW, Myers Jr MG, Billestrup N, Norstedt G, White MF and Carter-Su C. (1995). J. Biol. Chem., 270, $14685-14692$.

Asplin CM, Faria AC, Carlsen EC, Vaccaro VA, Barr RE, Iranmanesh A, Lee MM, Veldhuis JD and Evans WS. (1989). J. Clin. Endocrinol. Metab., 69, 239-245.

Beadling C, Ng J, Babbage JW and Cantrell DA. (1996). EMBO J., 15, $1902-1913$.

Benbassat C, Shoba LNN, Newman M, Adamo ML, Frank SJ and Lowe Jr WL. (1999). Endocrinology, 140, $3073-$ 3081.

Bergad PL, Shih H-M, Towle HC, Schwarzenberg SJ and Berry SA. (1995). J. Biol. Chem., 270, $24903-24910$.

Bergad PL, Towle HC and Berry SA. (2000). J. Biol. Chem., 275, 8114-8120.

Bichell DP, Kikuchi K and Rotwein P. (1992). Mol. Endocrinol., 6, $1899-1908$.

Billestrup N, Bouchelouche P, Allevato G, Ilondo M and Nielsen JH. (1995). Proc. Natl. Acad. Sci. USA, 92, $2725-$ 2729.

Billestrup N and Martin JM. (1985). Endocrinology, 116, $1175-1181$.

Boisclair YR, Seto D, Hsieh S, Hurst KR and Ooi GT. (1996). Proc. Natl. Acad. Sci. USA, 93, $10028-10033$.

Boucheron C, Dumon S, Santos SC, Moriggl R, Hennighausen L, Gisselbrecht S and Gouilleux F. (1998). J. Biol. Chem., 273, 33936-33941.

Campbell GS, Argetsinger LS, Ihle JN, Kelly PA, Rillema JA and Carter-Su C. (1994). Proc. Natl. Acad. Sci. USA, 91, $5232-5236$.

Campbell GS, Meyer DJ, Raz R, Levy DE, Schwartz J and Carter-Su C. (1995). J. Biol. Chem., 270, 3974-3979.

Carter-Su C, Stubbart JR, Wang X, Stred SE, Argetsinger LS and Shafer JA. (1989). J. Biol. Chem., 264, $18654-$ 18661.

Ceresa BP and Pessin JE. (1996). J. Biol. Chem., 271, 12121 12124.

Chen CM, Clarkson RW, Xie Y, Hume DA and Waters MJ. (1995). Endocrinology, 136, 4505-4516.

Dai J, Scott CD and Baxter RC. (1994). Endocrinology, 135, $1066-1072$.

Damen JE, Wakao H, Miyajima A, Krosl J, Humphries RK, Cutler RL and Krystal G. (1995). EMBO J., 14, 55575568 .

Darnell Jr JE, Kerr IM and Stark GR. (1994). Science, 264, $1415-1421$.

Davey HW, McLachlan MJ, Wilkins RJ, Hilton DJ and Adams TE. (1999a). Mol. Cell. Endocrinol., 158, 111-116.

Davey HW, Park S-H, Grattan DR, McLachlan MJ and Waxman DJ. (1999b). J. Biol. Chem., 274, 35331 - 35336.

Davey HW, Wilkins RJ and Waxman DJ. (1999c). Am. J. Hum. Genet., 65, 959-965.

David M, Petricoin III, E, Benjamin C, Pine R, Weber MJ and Larner AC. (1995). Science, 269, $1721-1723$.

David M, Zhou G, Pine R, Dixon JE and Larner AC. (1996). J. Biol. Chem., 271, $15862-15865$.

Durbin JE, Hackenmiller R, Simon MC and Levy DE. (1996). Cell, 84, 443-450.

Eden S, Schwartz J and Kostyo JL. (1982). Endocrinology, 111, $1505-1512$.

Eilers A, Georgellis D, Klose B, Schindler C, Ziemiecki A, Harpur AG, Wilks AF and Decker T. (1995). Mol. Cell. Biol., 15, 3579-3586.

Enberg G, Hulthen A, Moller C, Norstedt G and Francis SM. (1994). J. Mol. Endocrinol., 12, 39-46.

Endo TA, Masuhara M, Yokouchi M, Suzuki R, Sakamoto H, Mitsui K, Matsumoto A, Tanimura S, Ohtsubo M, Misawa H, Miyazaki T, Leonor N, Taniguchi T, Fujita T, Kanakura Y, Komiya S and Yoshimura A. (1997). Nature, 387, $921-924$.

Fain JN, Ihle JH and Bahouth SW. (1999). Biochem. Biophys. Res. Comm., 263, 201-205.

Favre H, Benhamou A, Finidori J, Kelly PA and Edery M. (1999). FEBS Lett., 453, $63-66$.

Feng GS, Hui CC and Pawson T. (1993). Science, 259, $1607-$ 1611.

Fernandez L, Flores-Morales A, Lahuna O, Sliva D, Norstedt G, Haldosen LA, Mode A and Gustafsson JA. (1998). Endocrinology, 139, 1815-1824.

Foster CM, Shafer JA, Rozsa FW, Wang X, Lewis SD, Renken DA, Natale JE, Schwartz J and Carter-Su C. (1988). Biochemistry, 27, 326-334.

Freeth JS, Silva CM, Whatmore AJ and Clayton PE. (1998). Endocrinology, 139, 20-28.

Fu X-Y. (1992). Cell, 70, 323-335.

Fujii H, Nakagawa Y, Schindler U, Kawahara A, Mori H, Gouilleux F, Groner B, Ihle JN, Minami Y, Miyazaki T and Taniguchi T. (1995). Proc. Natl. Acad. Sci. USA, 92, $5482-5486$.

Fujitani Y, Hibi M, Fukada T, Takahashi-Tezuka M, Yoshida H, Yamaguchi T, Sugiyama K, Yamanaka Y, Nakajima K and Hirano T. (1997). Oncogene, 14, 751761. 
Galsgaard ED, Gouilleux F, Groner B, Serup P, Nielsen JH and Billestrup N. (1996). Mol. Endocrinol., 10, 652-660.

Gebert CA, Park S-H and Waxman DJ. (1999a). Mol. Endocrinol., 13, $38-56$.

Gebert CA, Park SH and Waxman DJ. (1997). Mol. Endocrinol., 11, 400-414.

Gebert CA, Park SH and Waxman DJ. (1999b). Mol. Endocrinol., 13, 213-227.

Gerhartz C, Heesel B, Sasse J, Hemmann U, Landgraf C, Schneider-Mergener J, Horn F, Heinrich PC and Graeve L. (1996). J. Biol. Chem., 271, $12991-12998$.

Gouilleux F, Pallard C, Dusanter-Fourt I, Wakao H, Haldosen LA, Norstedt G, Levy D and Groner B. (1995). EMBO J., 14, 2005-2013.

Gouilleux F, Wakao H, Mundt M and Groner B. (1994). EMBO J., 13, $4361-4369$.

Goujon L, Allevato G, Simonin G, Paquereau L, Le Cam A, Clark J, Nielsen JH, Djiane J, Postel-Vinay MC, Edery M and Kelly PA. (1994). Proc. Natl. Acad. Sci. USA, 91, 957-961.

Greenlund AC, Farrar MA, Viviano B and Schreiber RD. (1994). EMBO J., 13, 1591-1600.

Gronowski AM and Rotwein P. (1994). J. Biol. Chem., 269 , $7874-7878$.

Gronowski AM, Zhong Z, Wen Z, Thomas MJ, Darnell Jr JE and Rotwein P. (1995). Mol. Endocrinol., 9, 171-177.

Hackett RH, Wang YD and Larner AC. (1995). J. Biol. Chem., 270, 21326-21330.

Hackett RH, Wang YD, Sweitzer S, Feldman G, Wood WI and Larner AC. (1997). J. Biol. Chem., 272, 11128-11132.

Han Y, Leaman DW, Watling D, Rogers NC, Groner B, Kerr IM, Wood WI and Stark GR. (1996). J. Biol. Chem., 271, 5947-5952.

Hansen JA, Lindberg K, Hilton DJ, Nielsen JH and Billestrup N. (1999). Mol. Endocrinol., 13, 1832 - 1843.

Hansen LH, Wang X, Kopchick JJ, Bouchelouche P, Nielsen JH, Galsgaard ED and Billestrup N. (1996). J. Biol. Chem., 271, $12669-12673$.

Haque SJ, Harbor P, Tabrizi M, Yi T and Williams BRG. (1998). J. Biol. Chem., 273, $33893-33896$.

Herrington J, Diakonova M, Rui L, Gunter DR and CarterSu C. (2000). J. Biol. Chem., in press.

Herrington J, Rui L, Luo G, Yu-Lee L-Y and Carter-Su C. (1999). J. Biol. Chem., 274, 5138-5145.

Hou J, Schindler U, Henzel WJ, Wong SC and McKnight SL. (1995). Immunity, 2, $321-329$.

Ihle JN. (1996). Cell, 84, 331-334.

Isgaard J, Moller C, Isaksson OGP, Nilsson A, Mathews LS and Norstedt G. (1988). Endocrinology, 122, 1515-1520.

Itoh T, Liu R, Yokota T, Arai KI and Watanabe S. (1998). Mol. Cell. Biol., 18, $742-752$.

Jiao H, Berrada K, Yang W, Tabrizi M, Platanias LC and Yi T. (1996). Mol. Cell. Biol., 16, 6985-6992.

Johnson HM, Torres BA, Green MM, Szente BE, Siler KI, Larkin III J and Subramaniam PS. (1998a). Biochem. Biophys. Res. Commun., 244, 607-614.

Johnson HM, Torres BA, Green MM, Szente BE, Siler KI, Larkin III J and Subramaniam PS. (1998b). Proc. Soc. Exp. Biol. Med., 218, 149-155.

Johnson RJ. (1988). J. Endocrinol., 119, $101-109$.

Karlsson H, Gustafsson JA and Mode A. (1999). Mol. Cell. Endocrinol., 152, 37 - 43 .

Kazansky AV, Raught B, Lindsey SM, Wang Y-f and Rosen JM. (1995). Mol. Endocrinol., 9, 1598-1609.

Kessler DS, Veals SA, Fu X-Y and Levy DE. (1990). Genes Dev., 4, $1753-1765$.

Kim SO, Jiang J, Yi W, Feng GS and Frank SJ. (1998). J. Biol. Chem., 273, 2344-2354.

Klingmuller U, Lorenz U, Cantley LC, Neel BG and Lodish HF. (1995). Cell, 80, 729-738.

Le Stunff C and Rotwein P. (1998). Endocrinology, 139, 859 866.
LeCam A, Pages G, Auberger P, LeCam G, Leopold P, Benarous R and Glaichenhaus N. (1987). EMBO J., 6, $1225-1232$

LeCam A, Pantescu V, Paquereau L, Legraverend C, Fauconnier G and Asins G. (1994). J. Biol. Chem., 269, $21532-21539$

Legraverend C, Mode A, Westin S, Strom A, Eguchi H, Zaphiropoulos PG and Gustafsson J. (1992). Mol. Endocrinol., 6, 259-266.

Leung DW, Spencer SA, Cachianes G, Hammonds RG, Collins C, Henzel WJ, Barnard R, Waters MJ and Wood WI. (1987). Nature, 330, 537-543.

Lin JX, Mietz J, Modi WS, John S and Leonard WJ. (1996). J. Biol. Chem., 271, $10738-10744$.

Liu X, Gallego MI, Smith GH, Robinson GW and Hennighausen L. (1998). Cell Growth Differ., 9, 795-803.

Liu X, Robinson GW, Gouilleux F, Groner B and Hennighausen L. (1995). Proc. Natl. Acad. Sci. USA, 92 , $8831-8835$

Liu X, Robinson GW and Hennighausen L. (1996). Mol. Endocrinol., 10, 1496-1506.

Liu X, Robinson GW, Wagner KU, Garrett L, WynshawBoris A and Hennighausen L. (1997). Genes Dev., 11, $179-186$.

Marte BM, Meyer T, Stabel S, Standke GJ, Jaken S, Fabbro D and Hynes NE. (1994). Cell Growth Differ., 5, 239-247.

Mathews LS, Norstedt G and Palmiter RD. (1986). Proc. Natl. Acad. Sci. USA 83, 9343-9347.

Matsumoto A, Seki Y, Kubo M, Ohtsuka S, Suzuki A, Hayashi I, Tsuji K, Nakahata T, Okabe M, Yamada S and Yoshimura A. (1999). Mol. Cell. Biol., 19, 6396-6407.

Meraz MA, White JM, Sheehan KC, Bach EA, Rodig SJ, Dighe AS, Kaplan DH, Riley JK, Greenlund AC, Campbell D, Carver-Moore K, DuBois RN, Clark R, Aguet M and Schreiber RD. (1996). Cell, 84, 431-442.

Meton I, Boot EP, Sussenbach JS and Steenbergh PH. (1999). FEBS Lett., 444, 155- 159.

Meyer DJ, Campbell GS, Cochran BH, Argetsinger LS, Larner AC, Finbloom DS, Carter-Su C and Schwartz J. (1994). J. Biol. Chem., 269, 4701-4704.

Moldrup A, Billestrup N, Dryberg T and Nielsen JH. (1991) J. Biol. Chem., 266, $17441-17445$.

Moriggl R, Gouilleux-Gruart V, Jahne R, Berchtold S, Gartmann C, Liu X, Hennighausen L, Sotiropoulos A, Groner B and Gouilleux F. (1996). Mol. Cell. Biol., 16, $5691-5700$.

Mui AL, Wakao H, AM OF, Harada N and Miyajima A. (1995). EMBO J., 14, 1166-1175.

Muller M, Briscoe J, Laxton C, Guschin D, Ziemiecki A, Silvennoinen O, Harpur AG, Barbieri G, Witthuhn BA and Schindler C. (1993). Nature, 366, 129-135.

Naka T, Narazaki M, Hirata M, Matsumoto T, Minamoto S, Aono A, Nishimoto N, Kajita T, Taga T, Yoshizaki K, Akira S and Kishimoto T. (1997). Nature, 387, 924-929.

Narazaki M, Fujimoto M, Matsumoto T, Morita Y, Saito H, Kajita T, Yoshizaki K, Naka T and Kishimoto T. (1998). Proc. Natl. Acad. Sci. USA, 95, 13130-13134.

Nebert DW. (1991). Mol. Endocrinol., 5, 1203-1214.

Nebert DW, Nelson DR, Coon MJ, Estabrook RW, Feyereisen R, Fujii-Kuriyama Y, Gonzalez FJ, Guengerich FP, Gunsalus IC and Johnson EF. (1991). DNA Cell. Biol., 10, $1-14$

Ooi GT, Cohen FJ, Tseng LY, Rechler MM and Boisclair YR. (1997). Molec. Endocrinol., 11, 997-1007.

Paquereau L, Vilarem MJ, Rossi V, Rouayrenc JF and Le Cam A. (1992). Eur. J. Biochem., 209, 1053-1061.

Park SH, Liu X, Hennighausen L, Davey HW and Waxman DJ. (1999). J. Biol. Chem., 274, $7421-7430$.

Peter MA, Winterhalter KH, Peter MA, Boni-Schnetzler M, Froesch ER and Zapf J. (1993). Endocrinology, 133, $2624-2631$ 
Pezet A, Ferrag F, Kelly PA and Edery M. (1997). J. Biol. Chem., 272, 25043-25050.

Pircher TJ, Flores-Morales A, Mui AL, Saltiel AR, Norstedt G, Gustafsson JA and Haldosen LA. (1997). Mol. Cell. Endocrinol. 133, 169-176.

Quelle FW, Thierfelder W, Witthuhn BA, Tang B, Cohen S and Ihle JN. (1995). J. Biol. Chem., 270, 20775-20780.

Quelle FW, Wang D, Nosaka T, Thierfelder WE, Stravopodis D, Weinstein Y and Ihle JN. (1996). Mol. Cell. Biol., 16, $1622-1631$.

Ram PA, Park SH, Choi HK and Waxman DJ. (1996). J. Biol. Chem., 271, 5929-5940.

Ram PA and Waxman DJ. (1997). J. Biol. Chem., 272, $17694-17702$.

Ram PA and Waxman DJ. (1999). J. Biol. Chem., 274, $35553-35561$

Raz R, Durbin JE and Levy DE. (1994). J. Biol. Chem., 269, $24391-24395$

Ripperger JA, Fritz S, Richter K, Hocke GM, Lottspeich F and Fey GH. (1995). J. Biol. Chem., 270, 29998 - 30006.

Robertson LM, Kerppola TK, Vendrell M, Luk D, Smeyne RJ, Bocchiaro C, Morgan JI and Curran T. (1995). Neuron, 14, $241-252$.

Rui L and Carter-Su C. (1999). Proc. Natl. Acad. Sci. USA, 96, $7172-7177$

Rui L, Mathews LS, Hotta K, Gustafson TA and Carter-Su C. (1997). Mol. Cell Biol., 17, 6633-6644.

Schmitt-Ney M, Happ B, Ball RK and Groner B. (1992). Proc. Natl. Acad. Sci. USA, 89, 3130-3134.

Sekimoto $\mathrm{T}$, Imamoto $\mathrm{N}$, Nakajima $\mathrm{K}$, Hirano $\mathrm{T}$ and Yoneda Y. (1997). EMBO J., 16, $7067-7077$.

Sekimoto $T$, Nakajima $K$, Tachibana $T$, Hirano $T$ and Yoneda Y. (1996). J. Biol. Chem., 271, 31017-31020.

Shuai K, Schindler C, Prezioso VR and Darnell Jr JE. (1992). Science, 258, $1808-1812$.

Shuai K, Stark GR, Kerr IM and Darnell Jr JE. (1993). Science, 261, 1744-1746.

Silva CM, Lu H and Day RN. (1996). Mol. Endocrinol., 10, $508-518$

Silvennoinen O, Ihle JN, Schlessinger J and Levy DE. (1993) Nature, 366, $583-585$.

Simar-Blanchet AE, Legraverend C, Thissen JP and Le Cam A. (1998). Mol. Endocrinol., 12, 391-404.

Sliva D, Wood TJJ, Schindler C, Lobie PE and Norstedt G. (1994). J. Biol. Chem., 42, 26208-26214.

Smit LS, Meyer DJ, Argetsinger LS, Schwartz J and CarterSu C. (1999). Handbook of Physiology, Vol. V. Kostyo JL. (ed.). Oxford University Press: New York, pp. 445-480.

Smit LS, Meyer DJ, Billestrup N, Norstedt G, Schwartz J and Carter-Su C. (1996). Mol. Endocrinol., 10, 519-533.

Smit LS, VanderKuur JA, Stimage A, Han Y, Luo G, Yu-lee L, Schwartz J and Carter-Su C. (1997). Endocrinology, 138, 3426-3434.

Sotiropoulos A, Moutoussamy S, Binart N, Kelly PA and Finidori J. (1995). FEBS Lett., 369, 169-172.

Sotiropoulos A, Moutoussamy S, Renaudie F, Clauss M, Kayser C, Gouilleux F, Kelly PA and Finidori J. (1996). Mol. Endocrinol., 10, $998-1009$.

Stahl N, Farruggella TJ, Boulton TG, Zhong Z, Darnell Jr JE and Yancopoulos GD. (1995). Science, 267, 13491353.

Starr R, Willson TA, Viney EM, Murray LJ, Rayner JR, Jenkins BJ, Gonda TJ, Alexander WS, Metcalf D, Nicola NA and Hilton DJ. (1997). Nature, 387, $917-921$.

Stofega MR, Wang H, Ullrich A and Carter-Sue C. (2000). J. Biol. Chem., Submitted.

Stofega MR, Wang H, Ullrich A and Carter-Su C. (1998). J. Biol. Chem., 273, 7112-7117.

Strehlow I and Schindler C. (1998). J. Biol. Chem., 273, $28049-28056$.

Subramanian A, Teixeira J, Wang J and Gil G. (1995). Mol. Cell. Biol., 15, $4672-4682$.
Sundseth SS, Alberta JA and Waxman DJ. (1992). J. Biol. Chem., 267, 3907-3914.

Takeda K, Noguchi K, Shi W, Tanaka T, Matsumoto M, Yoshida N, Kishimoto T and Akira S. (1997). Proc. Natl. Acad. Sci. USA, 94, $3801-3804$.

Tannenbaum GS and Martin JB. (1976). Endocrinology, 98, $562-570$

Teglund S, McKay C, Schuetz E, van Deursen JM, Stravopodis D, Wang D, Brown M, Bodner S, Grosveld G and Ihle JN. (1998). Cell, 93, $841-850$.

Tollet-Egnell P, Flores-Morales A, Stavreus-Evers A, Sahlin L and Norstedt G. (1999). Endocrinology, 140, 36933704.

Tourkine N, Schindler C, Larose $\mathrm{M}$ and Houdebine LM. (1995). J. Biol. Chem., 270, 20952-20961.

Udy GB, Towers RP, Snell RG, Wilkins RJ, Park SH, Ram PA, Waxman DJ and Davey HW. (1997). Proc. Natl. Acad. Sci. USA, 94, $7239-7244$.

van Dijk TB, Caldenhoven E, Raaijmakers JA, Lammers JW, Koenderman L and de Groot RP. (1997). FEBS Lett., 412, 161 - 164 .

Verdier F, Chretien S, Muller O, Varlet P, Yoshimura A, Gisselbrecht S, Lacombe C and Mayeux P. (1998). J. Biol. Chem., 273, 28185-28190.

Wakao H, Gouilleux F and Groner B. (1994). EMBO J., 13, $2182-2191$.

Wang X, Darus CJ, Xu BC and Kopchick JJ. (1996). Mol. Endocrinol., 10, $1249-1260$.

Wang X, Moller C, Norstedt G and Carter-Su C. (1993). J. Biol. Chem., 268, 3573-3579.

Wang Y-D, Wong K and Wood WI. (1995). J. Biol. Chem., 270, $7021-7024$.

Wang YD and Wood WI. (1995). Mol. Endocrinol., 9, $303-$ 311 .

Wartmann M, Cella N, Hofer P, Groner B, Liu X, Hennighausen L and Hynes NE. (1996). J. Biol. Chem., 271, 31863-31868

Watling D, Guschin D, Muller M, Silvennoinen O, Witthuhn BA, Quelle FW, Rogers NC, Schindler C, Stark GR, Ihle JN and Kerr IM. (1993). Nature, 366, 166-170.

Waxman DJ, Ram PA, Park SH and Choi HK. (1995). J. Biol. Chem., 270, $13262-13270$.

Wegenka UM, Lutticken C, Buschmann J, Yuan J, Lottspeich F, Muller-Esterl W, Schindler C, Roeb E, Heinrich PC and Horn F. (1994). Mol. Cell. Biol., 14, $3186-3196$.

Wen Z, Zhong Z and Darnell Jr JE. (1995). Cell, 82, $241-$ 250 .

Winer LM, Shaw MA and Baumann G. (1990). J. Clin. Endocrinol. Metab., 70, $1678-1686$.

Wood TJ, Sliva D, Lobie PE, Pircher TJ, Gouilleux F, Wakao H, Gustafsson JA, Groner B, Norstedt G and Haldosen LA. (1995). J. Biol. Chem., 270, 9448 - 9453.

Xu BC, Wang X, Darus CJ and Kopchick JJ. (1996). J. Biol. Chem., 271, $19768-19773$.

Yasukawa H, Misawa H, Sakamoto H, Masuhara M, Sasaki A, Wakioka T, Ohtsuka S, Imaizumi T, Matsuda T, Ihle JN and Yoshimura A. (1999). EMBO J., 18, 1309-1320.

Yi T, Mui AL-F, Krystal G and Ihle JN. (1993). Mol. Cell. Biol., 13, 7577-7586.

Yi W, Kim SO, Jiang J, Park SH, Kraft AS, Waxman DJ and Frank SJ. (1996). Mol. Endocrinol., 10, 1425-1443.

Yoon JB, Berry SA, Seelig S and Towle HC. (1990). J. Biol. Chem., 265, $19947-19954$.

Yoon JB, Towle HC and Seeling S. (1987). J. Biol. Chem., 262, 4284-4289.

Yoshimura A, Ohkubo T, Kiguchi T, Jenkins NA, Gilbert DJ, Copeland NG, Hara T and Miyajima A. (1995). EMBO J., 14, 2816-2826.

Yu C-L, Jin Y-J and Burakoff SJ. (2000). J. Biol. Chem., 275, 599-604. 
Zhang X, Blenis J, Li HC, Schindler C and Chen-Kiang S. (1995). Science, 267, 1990-1994.

Zhong A, Wen A and Darnell Jr JE. (1994). Proc. Natl. Sci. U.S.A., 91, 4806-4810.
Zhu T, Goh EL and Lobie PE. (1998a). J. Biol. Chem., 273, $10682-10689$.

Zhu T, Goh ELK, LeRoith D and Lobie PE. (1998b). J. Biol. Chem., 273, 33864-33875. 